\title{
Thermal balance of Nellore cattle
}

\author{
Cíntia Carol de Melo Costa ${ }^{1} \cdot$ Alex Sandro Campos Maia ${ }^{1} \cdot$ Sheila Tavares Nascimento $^{2}$ • \\ Carolina Cardoso Nagib Nascimento ${ }^{1} \cdot$ Marcos Chiquitelli Neto $^{3} \cdot$ Vinícius de França \\ Carvalho Fonsêca ${ }^{1}$
}

\begin{abstract}
This work aimed at characterizing the thermal balance of Nellore cattle from the system of indirect calorimetry using a facial mask. The study was conducted at the Animal Biometeorology Laboratory of the São Paulo State University, Jaboticabal, Brazil. Five male Nellore weighing $750 \pm 62 \mathrm{~kg}$, at similar ages and body conditions were distributed in four $5 \times 5$ Latin squares (5 days of records and five schedules) during 20 days. Physiological and environmental measurements were obtained from the indirect calorimetry system using a facial mask. Respiratory parameters, hair coat, skin, and rectal temperature were continuously recorded. From this,
\end{abstract}

Cíntia Carol de Melo Costa

cintiacarolmc@yahoo.com.br

Alex Sandro Campos Maia

alex.maia@fcav.unesp.br

Sheila Tavares Nascimento

sheila_tn@terra.com.br

Carolina Cardoso Nagib Nascimento

carolnagib@yahoo.com.br

Marcos Chiquitelli Neto

manera@bio.feis.unesp.br

Vinícius de França Carvalho Fonsêca

vinicius_fonseca86@hotmail.com

1 Laboratory of Animal Biometeorology, Animal Science Department, Sao Paulo State University, Jaboticabal Campus, Access avenue Professor Paulo Donato Castellane, Jaboticabal, SP 14884-900, Brazil

2 Faculty of Agronomy and Veterinary Medicine, Universidade de Brasília, Brasília, Brazil

3 Biology and Animal Science Department, Sao Paulo State University, Ilha Solteira, SP 15385-000, Brazil metabolic heat production, sensible and latent ways of heat transfer were calculated. Metabolic heat production had an average value of $146.7 \pm 0.49 \mathrm{~W} \mathrm{~m}^{-2}$ and did not change $(P>0.05)$ over the range of air temperature (24 to $35^{\circ} \mathrm{C}$ ). Sensible heat flow reached $60.08 \pm 0.81 \mathrm{~W} \mathrm{~m}^{-2}$ when air temperature ranged from 24 to $25{ }^{\circ} \mathrm{C}$, being negligible in conditions of temperature above $33{ }^{\circ} \mathrm{C}$. Most of the heat produced by metabolism was dissipated by cutaneous evaporation when air temperature was greater than $30^{\circ} \mathrm{C}$. Respiratory parameters like respiratory rate and ventilation remained stable $(P>0.05)$ in the range of temperature studied. Under shade conditions and air temperature range from 24 to $35^{\circ} \mathrm{C}$, metabolic heat production, respiratory rate, and ventilation of mature Nellore cattle remain stable, which is indicative of low energetic cost to the thermoregulation.

Keywords Thermoregulation - Indirect calorimetry ·

Metabolic heat production $\cdot$ Latent heatloss $\cdot$ Sensible heat flux

\section{Introduction}

+ Nellore cattle (Bos indicus) was brought from India to Brazil in the nineteenth century; these animals survived and reproduced, consequently adapted in the new environment. Actually, these animals are managed on pasture systems, which were exposed to direct solar radiation and high temperatures; these conditions pose challenges to European breeds. Little investigation has addressed the phenotypic aspects of Nellore animals that favor their adaptation to tropical regions. In one of the reports, da Silva et al. (2003) described a cutaneous surface with white, short, and dense hair coat, covered with highly pigmented skin, which differs substantially from those cattle selected in temperate zones. 
Few authors have focused on the physiological responses of Nellore animals to environmental factors (McManus et al. 2009, 2011), and no studies specifically addressed their thermal equilibrium. Furthermore, findings that aimed at explaining thermal balance in cattle did so under controlled environmental conditions in climatic chambers (Gonzalez and Blaxter 1962; McLean 1963a, b; Holmes and McLean 1975; Gebremedhin et al. 1981; McLean et al. 1984; Schrama et al. 1992; Gaughan et al. 1999; Lighton 2008) which differ completely from those found in field, where animals face a complex environment, and factors such as wind speed, radiation, air temperature, and humidity change continuously. Therefore, the present study further characterizes the thermal equilibrium of mature Nellore cattle using an indirect calorimetry system with facial mask. Our investigation may contribute to breeding programs targeting individuals with tolerance to high temperatures, improving cattle handling, thermal comfort, and productivity.

\section{Materials and methods}

\section{Animals, experimental design, and management}

This research was reviewed and approved by the Sao Paulo State University Animal Care and Use Committee before the study started (Process number: 17.519/14). The study was conducted at the Biometeorology Laboratory of the School of Agricultural and Veterinary Sciences, Sao Paulo State University (FCAV-UNESP), Jaboticabal, SP, Brazil ( $21^{\circ} 08^{\prime}$ $\mathrm{S}, 48^{\circ} 11^{\prime} \mathrm{W}, 583-\mathrm{m}$ altitude). Five non-castrated Nellore male with 2.5 years, divided in two class of body weight (1-animals with body mass higher than $750 \mathrm{~kg}$ and 2 - animals with body mass lower than $750 \mathrm{~kg}$ ) were assigned in four $5 \times 5$ Latin squares ( 5 days of records and five schedules) during 20 days. Data were collected from 08:00 to 18:00 h each day with animals protected from direct solar radiation; the first individual was evaluated from 08:00 to 10:00 $\mathrm{h}$; the second from 10:00 to $12: 00 \mathrm{~h}$, and so on until the fifth animal was evaluated from 16:00 to 18:00 h. At the end of the trial, all animals were evaluated in each time period. Animals were fed twice daily, with forage (corn silage; $70 \%$ ) and concentrate (corn, soybean, and urea; $30 \%$ ) at a total mixed ration; water was provided ad libitum. Daily feed consumption was approximately $2.5 \%$ of the body weight.

\section{Meteorological variables}

Air temperature $\left(T_{\mathrm{A}},{ }^{\circ} \mathrm{C}\right)$, relative humidity $\left(R_{\mathrm{H}}, \%\right)$, black globe temperature in shade $\left(T_{\mathrm{G}},{ }^{\circ} \mathrm{C}\right)$, and under direct sunlight $\left(T_{\mathrm{GSUN}},{ }^{\circ} \mathrm{C}\right.$ ) were measured at regular 1 -s intervals during each trial day with a Data Logger (model HOBO, onset). The black globe temperature was measured with a thermocouple (Type $\mathrm{K}$ ) inserted into the center of a hollow 0.15-m-diameter copper sphere, matt black painted, placed $50 \mathrm{~cm}$ above the ground. Furthermore, mean radiant temperature $\left(T_{\mathrm{RM}}, \mathrm{K}\right)$ in the shade and under the sun was obtained according to da Silva et al. (2010). A portable pyranometer (model CMP-22, Kipp and Zonen, Delft, Netherlands) was used to measure local solar irradiance $\left(G_{\mathrm{S}}, \mathrm{W} \mathrm{m}^{-2}\right)$ on a horizontal surface, in the 200-3600-nm spectral range. Recorded values correspond to the direct and diffuse short-wave solar radiation, and were measured at regular 10-min intervals during each day.

\section{Physiological parameters and the indirect calorimetry system}

The volumes $\left(\mathrm{L} \mathrm{s}^{-1}\right)$ of oxygen $\left(\mathrm{VO}_{2}\right)$, carbon dioxide $\left(\mathrm{VCO}_{2}\right)$, and water vapor $\left(\mathrm{H}_{2} \mathrm{O}\right)$ in the exhaled air of the cattle were measured by using an indirect calorimetry system coupled to a facial mask adjusted to the animals' muzzles (Fig. 1) similar to that used by Maia et al. (2016). The facial mask was designed to ensure that the volume of ventilated dead space $(\mathrm{Vd} \rightarrow 0)$ was as close to zero as possible, because it affects the true concentration of the expired gases; hence, the ratio $(K)$ of the respiratory tidal volume (VT) to $\mathrm{Vd}(\mathrm{K}=\mathrm{Vd} / \mathrm{VT})$ was as large as possible. The best geometry of the facial mask that reduced the $\mathrm{Vd}$ was an ellipsoidal shape with a $\mathrm{Vd}$ of approximately $0.2 \mathrm{~L}$ (Maia et al. 2014); prior to the study, animals were habituated and conditioned to the use facial mask using operant conditioning principles employing feed as a positive reinforcement (Camerro et al. 2016).

During each breath, the inflow (inspired air) and the outflow (exhaled air) passed through two valves. Exhaled air coming out from the facial mask was directed through a tracheal tube (MLA1015 Breathing Tube, ADInstruments, Australia) to the gas-mixing chamber (MLA246, ADInstruments, Australia). The gas-mixing chamber was connected to the Field Metabolic System (FMS-1201-05, Sable System, USA) through a plastic tube (Bevaline Tubing, Sable System, USA). An air pump at the FMS kept a continuous flow of exhaled air $\left(150 \mathrm{~mL} \mathrm{~min}^{-1}\right)$ through this tube and into a gas analyzer $\left(\mathrm{H}_{2} \mathrm{O}, \mathrm{O}_{2}\right.$, and $\left.\mathrm{CO}_{2}\right)$. The air sample first went into the $\mathrm{H}_{2} \mathrm{O}$ vapor analyzer and the dryer (magnesium perchlorate $\left.\left(\mathrm{Mg}\left(\mathrm{ClO}_{4}\right)_{2}\right)\right)$; then, it was carried through the $\mathrm{CO}_{2}$ and $\mathrm{O}_{2}$ analyzers; and finally to the $\mathrm{CH}_{4}$ analyzer (MA-10, Sable System, USA). Air leaving the mixing chamber went through a flow head (MLT 1000, ADInstruments, Australia) with a spirometer coupled to it (ML141, ADInstruments, Australia), which measured the respiratory rate $\left(R_{\mathrm{R}}\right.$, breaths $\left.\mathrm{min}^{-1}\right)$ and ventilation $\left(\mathrm{V}_{\mathrm{E}}, \mathrm{L} \mathrm{s}^{-1}\right)$. The FMS, the $\mathrm{CH}_{4}$ analyzer, the spirometer, the $\mathrm{H}_{2} \mathrm{O}$ vapor analyzer, and the thermocouples were connected to a data acquisition system (PowerLab 16/32, ADInstruments, Australia), which in turn was connected to a computer that recorded continuously and 
Fig. 1 Physiological measurement system developed for cattle

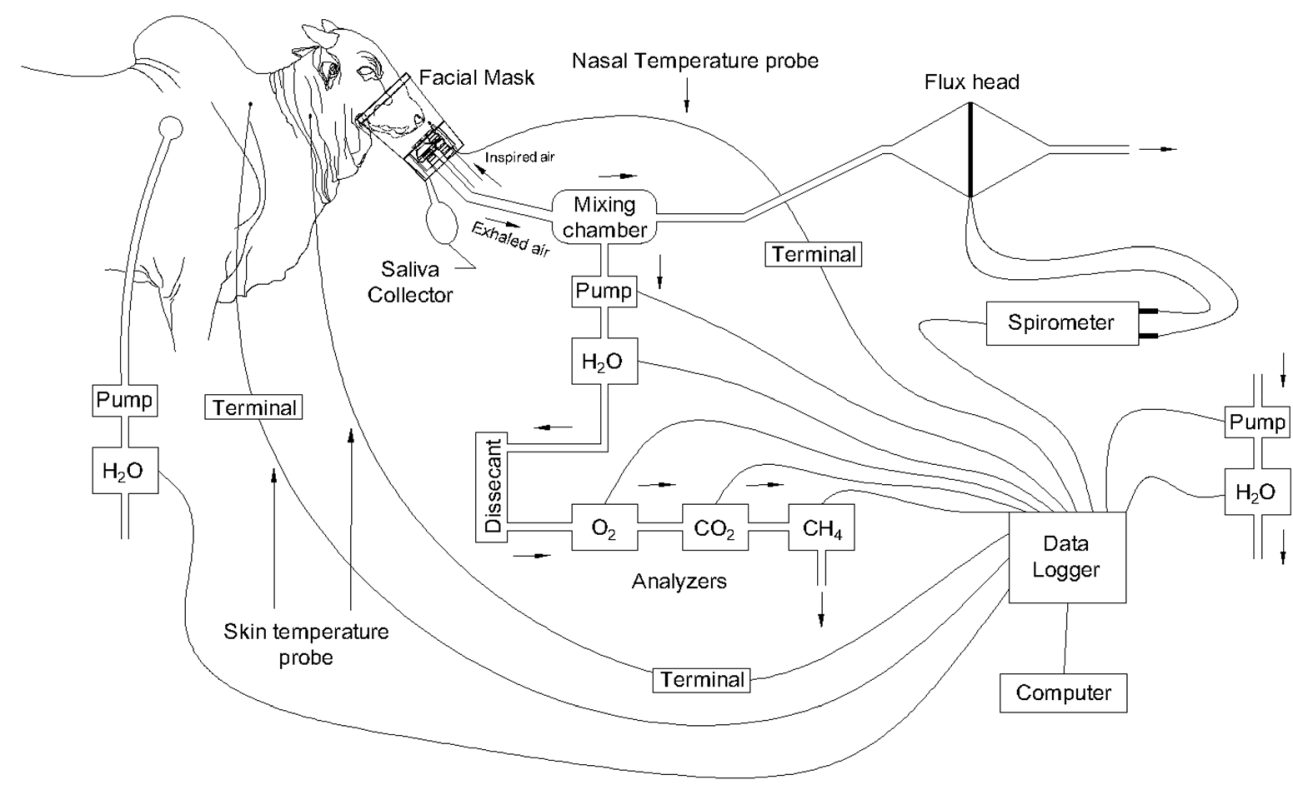

simultaneously all the measurements at a rate of one observation per second.

Proportions of oxygen and carbon dioxide in the atmosphere $\left(\mathrm{O}_{2 \mathrm{~A}}\right.$ and $\mathrm{CO}_{2 \mathrm{~A}}$, respectively) were analyzed by the FMS. These measurements were performed whenever the facial mask was placed on an animal's muzzle. Simultaneously, atmospheric vapor pressure was recorded by an external $\mathrm{H}_{2} \mathrm{O}$ vapor analyzer $\left(P_{\mathrm{V}}, \mathrm{kPa}\right)(\mathrm{RH}-300$, Sable System, USA) connected to a pump (SS4, Sable System, USA), which continuously aspirated samples of atmospheric air $\left(150 \mathrm{~mL} \mathrm{~min}^{-1}\right)$ from near the mask's influx valve. Moreover, body surface saturation pressure (Pcap $\left\{T_{\mathrm{EP}}\right\}$ ) was measured with a ventilated capsule (Maia et al. 2005a, b). A pump (SS4 Sable System, USA) was connected to the tube leaving the capsule. This equipment pulled the air through the influx tube, into the capsule, over the animal's body surface, and out into the vapor analyzer (RH-300, Sable System, USA).

The hair coat surface temperature $\left(T_{\mathrm{S}},{ }^{\circ} \mathrm{C}\right)$ was measured with a sensor (MLT 422A, ADInstruments, Australia, accuracy $\pm 0.3{ }^{\circ} \mathrm{C}$ ) placed on the back of the animals just under the hair coat surface. In the same body region, another temperature sensor (MLT 422A ADInstruments, Australia, accuracy $\left.\pm 0.3{ }^{\circ} \mathrm{C}\right)$ was used for the skin surface temperature $\left(T_{\mathrm{EP}},{ }^{\circ} \mathrm{C}\right)$, but in this case, the skin area was previously shaved. These sensors were fixed on the animal's surface with a plastic board, positioned above of the sensors, with the aid of an elastic belt around the animal's upper body. The rectal temperature $\left(T_{\mathrm{R}},{ }^{\circ} \mathrm{C}\right)$ was continuously recorded by a rectal thermocouple (MLT 1404, ADInstruments, Australia, accuracy $\pm 0.3{ }^{\circ} \mathrm{C}$ ). A nasal temperature sensor (MLT 415/AL, ADInstruments, Australia, accuracy $\pm 0.3{ }^{\circ} \mathrm{C}$ ) was placed inside the facial mask, just in front of the animal's nostrils, to measure the exhaled air temperature $\left(T_{\mathrm{EXH}},{ }^{\circ} \mathrm{C}\right)$.

\section{Thermal balance components}

\section{Metabolic heat production}

The volumes of $\mathrm{O}_{2}, \mathrm{CO}_{2}$, and $\mathrm{CH}_{4}\left(\mathrm{~L} \mathrm{~s}^{-1}\right)$ were calculated according to McLean (1972) and Brouwer (1965), using a Haldane transformation,

$$
\begin{aligned}
& \mathrm{VO}_{2}=V_{\mathrm{E}}\left[\mathrm{O}_{2 \mathrm{~A}}\left(\frac{1-\mathrm{O}_{2 \mathrm{~A}}-\mathrm{CO}_{2 \mathrm{~A}}-\mathrm{CH}_{4 \mathrm{~A}}}{1-\mathrm{O}_{2 \mathrm{E}}-\mathrm{CO}_{2 \mathrm{E}}-\mathrm{CH}_{4 \mathrm{E}}}\right)-\mathrm{O}_{2 \mathrm{E}}\right] \\
& \mathrm{VCO}_{2}=V_{\mathrm{E}}\left[\mathrm{CO}_{2 \mathrm{E}}-\mathrm{CO}_{2 \mathrm{~A}}\left(\frac{1-\mathrm{O}_{2 \mathrm{~A}}-\mathrm{CO}_{2 \mathrm{~A}}-\mathrm{CH}_{4 \mathrm{~A}}}{1-\mathrm{O}_{2 \mathrm{E}}-\mathrm{CO}_{2 \mathrm{E}}-\mathrm{CH}_{4 \mathrm{E}}}\right)\right] \\
& \mathrm{VCH}_{4}=V_{\mathrm{E}}\left[\mathrm{CH}_{4 \mathrm{E}}-\mathrm{CH}_{4 \mathrm{~A}}\left(\frac{1-\mathrm{O}_{2 \mathrm{~A}}-\mathrm{CO}_{2 \mathrm{~A}}-\mathrm{CH}_{4 \mathrm{~A}}}{1-\mathrm{O}_{2 \mathrm{E}}-\mathrm{CO}_{2 \mathrm{E}}-\mathrm{CH}_{4 \mathrm{E}}}\right)\right]
\end{aligned}
$$

The metabolic heat production $\left(q "{ }_{\text {met }}, \mathrm{W} \mathrm{m}^{-2}\right)$ was calculated in accordance with daSilva and Maia (2013):

$q_{\text {met }}^{\prime \prime}=\frac{16180 \mathrm{VO}_{2}+5160 \mathrm{VCO}_{2}-2420 \mathrm{VCH}_{4}}{A_{\mathrm{n}}}$

where $A_{\mathrm{n}}\left(\mathrm{m}^{2}\right)$ is the body surface area of the animal, estimated according to Finch (1985):

$A_{\mathrm{n}}=0.15 B_{\mathrm{W}}{ }^{0.5556}$

where $B_{\mathrm{W}}$ is the body weight of the animals $(\mathrm{kg})$.

\section{Latent heat loss}

Heat loss by respiratory tract The latent heat loss by respiratory system $\left(q "{ }_{\text {err }}, \mathrm{W} \mathrm{m}^{-2}\right)$ was calculated by considering the tidal volume $\left(V_{\mathrm{T}}, \mathrm{m}^{3}\right.$ breath $\left.^{-1}\right)$ and the difference between the 
humidity of the exhaled and inspired air (daSilva and Maia 2013).

$q_{\mathrm{er}}^{\prime \prime}=\frac{\lambda V_{\mathrm{T}} R_{\mathrm{R}}\left(\Psi_{\mathrm{E}}-\Psi_{\mathrm{A}}\right)}{A_{\mathrm{n}}}$

where $\lambda$ is the latent heat of water vaporization $\left(\mathrm{J} \mathrm{g}^{-1}\right), R_{\mathrm{R}}$ is the respiratory rate (breaths $\mathrm{s}^{-1}$ ), and $\Psi_{\mathrm{A}}$ and $\Psi_{\mathrm{E}}$ is the absolute humidity $\left(\mathrm{g} \mathrm{m}^{-3}\right)$ of the atmosphere and exhaled air, respectively.

Heat loss by cutaneous evaporation The ventilated capsule technique described by Maia et al. $(2005 \mathrm{a}, \mathrm{b})$ was used to measure cutaneous evaporation from the neck of the animal. A capsule measuring $7 \mathrm{~cm}$ in diameter was connected to a water vapor analyzer $\left(P_{\mathrm{V}}, \mathrm{kPa}\right.$; RH-300, Sable System, USA), and this analyzer was coupled to a pump (SS4, Sable System, USA). The output of the system was recorded by a computer, providing the actual atmospheric pressure $\left(P_{\mathrm{V}}, \mathrm{kPa}\right)$ and the partial vapor pressure in the capsule $\left(P_{\mathrm{CAP}}\right)$. The air flow rate through the capsule was kept constant at $1.88 \mathrm{~L} \mathrm{~min}^{-1}$, and surface temperatures inside and outside the capsule were the same, as required for valid estimates of skin water loss. Thus, latent heat flow by cutaneous evaporation $(q "$ es) was obtained as proposed by daSilva and Maia (2013):

$q_{\mathrm{es}}^{\prime \prime}=\mathrm{fc}\left(\Psi_{\mathrm{C}}-\Psi_{\mathrm{atm}}\right) A_{\mathrm{n}}{ }^{-1}$

where $\mathrm{fc}\left(\mathrm{m}^{3} \mathrm{~s}^{-1}\right)$ is the air flux leaving the capsule, $\Psi_{\mathrm{atm}}$ $\left(\mathrm{g} \mathrm{m}^{-3}\right)$ is the absolute humidity of the atmosphere, and the $\Psi_{\mathrm{c}}$ $\left(\mathrm{g} \mathrm{m}^{-3}\right)$ is the absolute humidity of the air leaving the capsule $\left(\mathrm{g} \mathrm{m}^{-3}\right)$, estimated by the equation:

$\Psi_{\mathrm{C}}=\frac{2166,87 P_{\mathrm{S}}\left\{T_{\mathrm{EP}}\right\}}{T_{\mathrm{EP}}}$

\section{Sensible heat flow}

The sensible heat flow $\left(\mathrm{W} \mathrm{m}^{-2}\right.$ ) was given by

$q_{\mathrm{sen}}{ }^{\prime \prime}=q_{\mathrm{rl}+} q_{\mathrm{conv}}$

where $q_{\text {sen }}$ is the total heat loss transferred by sensible ways; $q_{\mathrm{rl}}$ and $q_{\text {conv }}$ are the heat loss by long-wave radiation and convection $\left(\mathrm{W} \mathrm{m}^{-2}\right)$, respectively.

Long-wave radiation The heat exchange by long-wave radi-

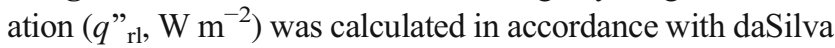
and Maia (2013):

$q_{\mathrm{rl}}^{\prime \prime}=\varepsilon \sigma\left(T_{\mathrm{S}}^{4}-T_{\mathrm{RM}}^{4}\right)$ where $\varepsilon$ is the emissivity of animal surface (Steketee 1973), $\sigma\left(5.67051 \times 10^{-8} \mathrm{~W} \mathrm{~m}^{-2} \mathrm{~K}^{-4}\right)$ is the Stefan-Boltzmann constant, $T_{\mathrm{S}}(\mathrm{K})$ is the coat surface temperature, and $T_{\mathrm{RM}}(\mathrm{K})$ is the mean radiant temperature.

Surface convection Heat flow by convection ( $q$ " ${ }_{\text {conv }}, \mathrm{W} \mathrm{m}^{-2}$ ) was calculated with the application of Newton's law of cooling, in accordance to Incropera et al. (2013):

$q_{\text {conv }}^{\prime \prime}=h_{\mathrm{C}}\left(T_{\mathrm{S}}-T_{\mathrm{A}}\right)$

where $h_{\mathrm{C}}$ is the coefficient of convection ( $\left.\mathrm{W} \mathrm{m}{ }^{-2} \mathrm{~K}\right), T_{\mathrm{S}}$ is the hair coat surface temperature $(\mathrm{K})$, and $T_{\mathrm{A}}$ is the air temperature $(\mathrm{K})$. The coefficient $h_{\mathrm{C}}$ was calculated assuming that the animal body was a horizontal cylinder with an average diameter of 1.3 and $1.1 \mathrm{~m}$ for animals with body weight $>750$ and $<750$, respectively.

\section{Statistical analysis}

-Data were analyzed by the least squares method (Harvey 1960) according to Littell and Freund (1991) for data composition, frequency distribution, descriptive statistics, and analyses of variance. Pearson correlations were tested. The mathematical model used to describe study variables was

$$
\begin{aligned}
Y_{\mathrm{ijklm}}= & \mu+P_{\mathrm{i}}+A_{\mathrm{j}}\left(P_{\mathrm{i}}\right)+Q_{\mathrm{k}}+D_{\mathrm{l}}\left(Q_{\mathrm{k}}\right)+T_{\mathrm{m}}+I_{\mathrm{im}} \\
& +e_{\mathrm{ijklm}}
\end{aligned}
$$

where $Y_{\mathrm{ijklm}}$ is the mth observation of the variables, $P$ is the fixed effect of ith weight class $(i=1>750 \mathrm{~kg}$ and $2<750 \mathrm{~kg}$ ), $A$ is the fixed effect of $j$ th animal $(j=1,2,3,4,5)$ within ith weight class, $Q$ is the fixed effect of the kth Latin square $(k=1,2,3,4), D$ is the fixed effect of the lth day within kth Latin square $(l=1,2, \ldots, 19,20 ; k=1,2,3,4), T$ is the fixed effect of $\mathrm{mth}$ class of air temperature $(\mathrm{m}=24,25,26, \ldots, 34$, $35), I$ is the interaction between ith weight and mth class of temperature, and $e_{\mathrm{ijklm}}$ is the residual term, including the random error and $\mu$ is the overall mean. The statistical package used for all analyses was SAS (SAS Institute 1995).

\section{Results and discussion}

The average air temperature, relative humidity, mean radiant temperature, and solar irradiance were $30.15 \pm 0.02{ }^{\circ} \mathrm{C}$, $60.91 \pm 0.09 \%, 31.71 \pm 0.03{ }^{\circ} \mathrm{C}$, and $530.73 \pm 2.71 \mathrm{~W} \mathrm{~m}^{-2}$, respectively (Fig. 2). $T_{\mathrm{A}}, R_{\mathrm{H}}$, as well as $G_{\mathrm{S}}$ had marked diurnal patterns with an amplitude of approximately $8{ }^{\circ} \mathrm{C}, 30 \%$, and $900 \mathrm{~W} \mathrm{~m}^{-2}$, respectively. In tropical environments, these amplitudes remain almost constant throughout the year. Whereas 
Fig. 2 Least square means $( \pm$ SEM) of meteorological variables during the experimental period
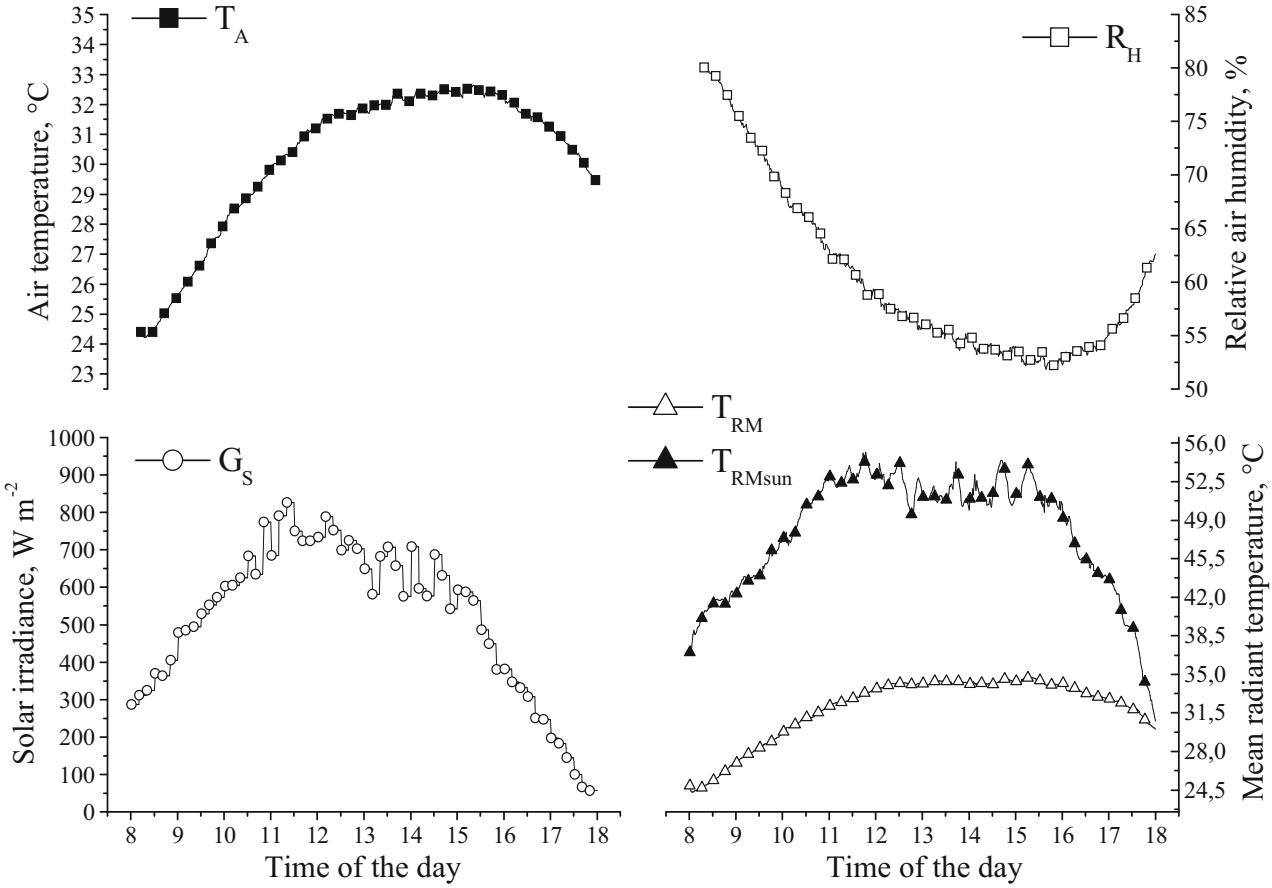

under temperate conditions, variations within a single day are smaller, but reach negative values because of the natural weather change during the year.

$T_{\mathrm{EP}}$ and $T_{\mathrm{S}}$ displayed a strong positive correlation and followed almost the same function with $T_{\mathrm{A}}\left(T_{\mathrm{EP}}=\mathrm{r} \rightarrow 0.67\right.$ and $T_{\mathrm{S}}=\mathrm{r} \rightarrow 0.71 ; P<0.05$; Figs. 2 and 3$)$. At a lower $T_{\mathrm{A}}$, the skin temperature remained $1{ }^{\circ} \mathrm{C}$ higher than surface temperature, on average. This result can be explained by the low hair coat resistance of Nellore cattle. These animals has a grayish hair coat with 0.56 reflectance, average thickness of $2.7 \mathrm{~mm}$, length of $14.3 \mathrm{~mm}$, diameter of $53.0 \mu \mathrm{m}$, and approximately 2083 hairs $\mathrm{cm}^{-2}$ (daSilva et al. 2003). Such hair coat reflects most of the short-wave radiation reaching it, while a highly pigmented skin underneath will absorb and protect against any ultraviolet radiation that passes through (Thomson 1962).

At thermal amplitude of $10{ }^{\circ} \mathrm{C}$, rectal temperature of the animals with body weight higher than $750 \mathrm{~kg}$ increased almost $1{ }^{\circ} \mathrm{C}$ throughout the day; this increase was less pronounced in animals with body weight lower than $750 \mathrm{~kg}$ (Fig. 3). Body heat content is the product of its heat capacity (body mass and specific heat) and the mean body temperature; as the specific heat can be considered a fixed value $\left(3.47 \mathrm{~J} \mathrm{~g}^{-1}{ }^{\circ} \mathrm{C}^{-1}\right)$, heavier animals have a greater capacity for heat storage than lighter animals (McLean et al. 1984; da Silva 2000); furthermore, due to their lower surface mass ratio, heavier animals are less susceptible to the variations of thermal environment. We use

Fig. 3 Least square means $( \pm \mathrm{SEM})$ of coat surface $\left(T_{\mathrm{S}},{ }^{\circ} \mathrm{C}\right)$, skin $\left(T_{\mathrm{EB}}{ }^{\circ} \mathrm{C}\right)$, and $\operatorname{rectal}\left(T_{\mathrm{R}},{ }^{\circ} \mathrm{C}\right.$ temperature. 1 animals with $B_{\mathrm{W}}$ $>750 \mathrm{~kg}, 2$ animals with $B_{\mathrm{W}}$ $<750 \mathrm{~kg}$

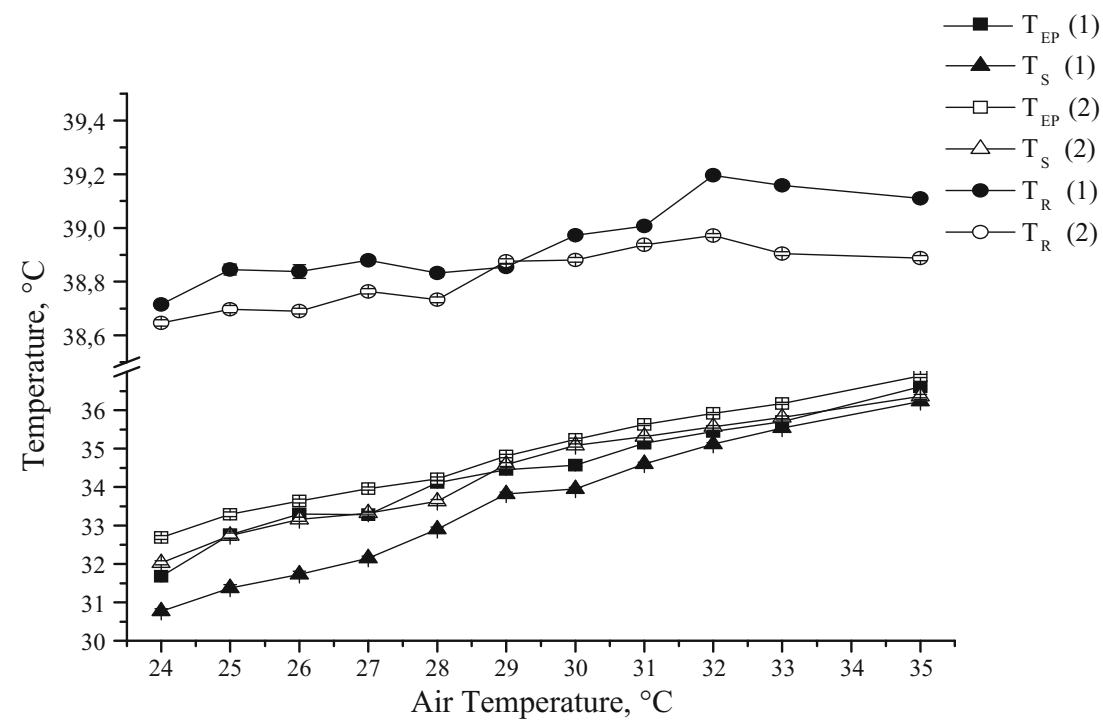


Fig. 4 Least square means of metabolic heat production $\left(q{ }_{\text {met }}\right)$, sensible heat flux $\left(q{ }^{\prime}\right.$ sen $)$, heat loss by cutaneous evaporation $\left(q{ }^{\prime}{ }_{\text {es }}\right)$, heat loss by respiratory evaporation $\left(q{ }^{\prime}{ }_{\mathrm{er}}\right)$, and latent heat flux ( $q$ "lat). 1 animals with $B_{\mathrm{W}}>750 \mathrm{~kg}, 2$ animals with $B_{\mathrm{W}}<750 \mathrm{~kg}$
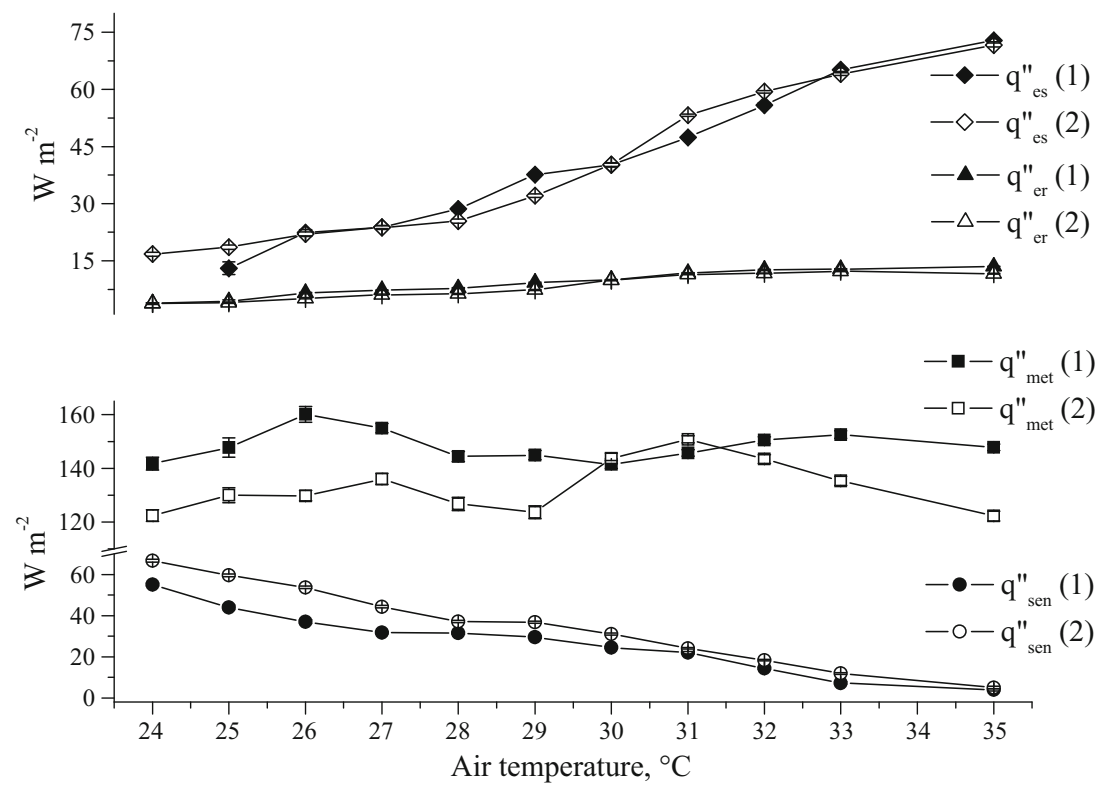

the rectal temperature as a convenient form to express the variation in the body heat content. Our results showed that variation in heat content was more pronounced in heavier animals. The law of energy conservation (Incropera 2013) describes that the rate of change of energy in a control volume is caused by the rates of energy flowing into and out of the control volume, which in a biologic system can be evaluated by the variation in metabolic heat production, sensible and latent ways for heat transfer.

The metabolic heat production displayed little variation in response to change in the air temperature (Fig. 4) for both class of weight, but do not differ statistically $(P>0.05)$; average metabolic heat production was $146.7 \pm 0.49 \mathrm{~W} \mathrm{~m}^{-2}$. We provide the first finding about metabolic heat production in growing Nellore cattle. Hansen (2004) suggested that the superior capacity for thermoregulation observed in Zebu cattle results from their lower metabolic heat production, which reflects in lower growth rate and milk production, in comparison to European breeds. In work with Angus heifers, Richardson et al. (2001) reported that their metabolic heat production remains at approximately $212 \mathrm{~W} \mathrm{~m}^{-2}$. Kibler and Brody (1956) assessed the influence of daily temperature cycles on metabolic heat production in Holstein cows. They found that these animals when exposed to a temperature variation between -12 and $4{ }^{\circ} \mathrm{C}$, their metabolic heat production ranged from 220 to $255 \mathrm{~W} \mathrm{~m}^{-2}$. However, when temperatures varied between 21 and $37.8^{\circ} \mathrm{C}$, the metabolic heat production ranged from 162 to $209 \mathrm{~W} \mathrm{~m}^{-2}$; these results provide evidence that even under high temperatures, Holstein cows have a higher metabolism in comparison to Nellore cattle.

There can be periods of imbalance between the rates of thermogenesis via metabolism and net of heat loss to the environment, resulting in positive or negative changes in body heat content (Findlay 1957; McLean et al. 1984). $T_{\mathrm{A}}$ displayed a strong and negative correlation with $q$ " $\operatorname{sen}(r=-0.81$, $P<0.05$; Fig. 4). Sensible (long-wave radiation and surface convection) heat flow reached $60.08 \pm 0.81 \mathrm{~W} \mathrm{~m}^{-2}$ when air temperature ranged from 24 to $25^{\circ} \mathrm{C}$, being negligible in conditions of temperature above $33^{\circ} \mathrm{C}$. Even under mild air temperature $\left(24\right.$ to $25^{\circ} \mathrm{C}$ ), the rate of sensible heat loss represented approximately $50 \%$ of the total metabolic heat production. The sensible heat flow depends on a temperature differential between the surface of the animals and the thermal environment; specifically, heat exchange by long-wave radiation is a function of the radiant mean temperature (daSilva et al. 2010). However, animals were evaluated in shade conditions, where the radiant mean temperature was very close to the air temperature. At the highest air temperatures, this thermal gradient difference decreased, reducing the heat flux to $5.90 \pm 0.61 \mathrm{~W} \mathrm{~m}^{-2}$. Maia et al. (2005a), working with Holstein cows, found that when the air temperature increased from 10 to $36{ }^{\circ} \mathrm{C}$, the sensible heat loss decreased from 160 to $-30 \mathrm{~W} \mathrm{~m}^{-2}$. In this situation, even in the shade, the mean radiant temperature was higher than surface temperature of animals and thus, long-wave radiation became a source of heat gain. When the sensible ways for heat transfer is negligible or a source of heat gain to the animals, latent heat loss becomes the major venue for dissipating the body heat (Collier and Gebremedhin 2015).

Latent heat loss followed the opposite pattern to sensible heat flow, reaching a higher value during the hottest times of the day (Fig. 4). Both evaporative losses had a strong positive correlation with $T_{\mathrm{A}}\left(q{ }_{\text {er }} \rightarrow r=0.81\right.$ and $q{ }_{\text {es }} \rightarrow r=0.94$; $P<0.05)$. At a $T_{\mathrm{A}}$ of $34{ }^{\circ} \mathrm{C}, q$ " es was $64.76 \pm 0.62 \mathrm{~W} \mathrm{~m}^{-2}$ and $q$ " er was $11.44 \pm 0.13 \mathrm{~W} \mathrm{~m}^{-2}$; latent ways represented $60 \%$ of the total metabolic heat production. McManus et al. 
Fig. 5 Ventilation $\left(V_{\mathrm{E}}\right)$ and respiratory rate $\left(R_{\mathrm{R}}\right) .1$ animals with $B_{\mathrm{W}}>750 \mathrm{~kg}, 2$ animals with $B_{\mathrm{W}}<750 \mathrm{~kg}$

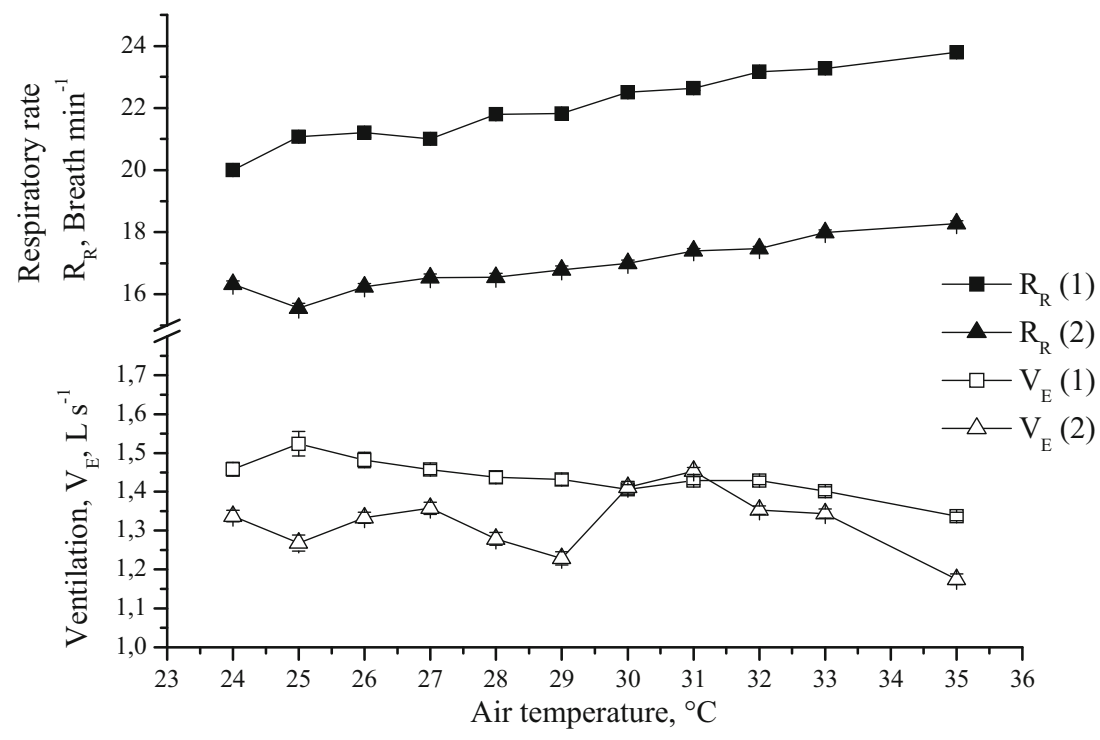

(2009) working with Nellore cattle and using the colorimetric method (Schleger and Turner 1965) found a cutaneous evaporation of approximately $149.74 \mathrm{~W} \mathrm{~m}^{-2}$ under similar thermal environment. This value is higher than reported here, possibly because of the differences between the method used; the colorimetric technique does not account for fur resistance and may absorb moisture from the atmosphere, leading to an overestimation of evaporation. Maia et al. (2005a) used the ventilated capsule method and measured cutaneous evaporation from 30 to $350 \mathrm{~W} \mathrm{~m}^{-2}$ in Holstein cows when air temperature increased from 10 to $30{ }^{\circ} \mathrm{C}$. Gebremedhin et al. (2008) measured the sweating rate of cows and Holstein heifers using a portable calorimeter. These animals were exposed to direct solar radiation (average of $500 \mathrm{~W} \mathrm{~m}^{-2}$ ) and an average of air temperature of $38.8^{\circ} \mathrm{C}$; cutaneous evaporation ranged from 126 to $348 \mathrm{~W} \mathrm{~m}^{-2}$. It is evident that cutaneous evaporation represents an important mechanism for thermoregulation in cattle, but with different magnitudes between breeds. Beside the difference in the metabolic heat production between then and environmental conditions, Zebu cattle seems to use this mechanism in a more moderate way, which can be an indicative of adaptive strategy that leads to a greater saving of water and metabolizable energy.

Heat loss by respiratory system is dependent on the ventilation, which is function of the tidal volume and respiratory rate (daSilva et al. 2002; Maia et al. 2005b; Fonsêca et al. 2016). According to our results, animals had an $R_{\mathrm{R}}$ of approximately 19 breaths $\mathrm{min}^{-1}$, and $V_{\mathrm{E}}$ of $1.38 \pm 0.004 \mathrm{~L} \mathrm{~s}^{-1}$ regardless of an air temperature variation from $24^{\circ}$ to $35^{\circ} \mathrm{C}$ (Fig. 5). Both measures do not presented significantly $(P>0.05)$ variation over this range of ambient temperature. Furthermore, heavier animals have a higher $(P<0.05) R_{\mathrm{R}}$ and $V_{\mathrm{E}}$ in comparison to lighter individuals. Using an electronic device, Milan et al. (2016) measured respiratory rate from 24 to 30 breaths $\mathrm{min}^{-1}$ in mature Nellore males exposed to direct solar radiation (range from 250 to $850 \mathrm{~W} \mathrm{~m}^{-2}$ ). Previous work with several Brazilian Zebu breeds found an average $R_{\mathrm{R}}$ of 28 breaths $\min ^{-1}$ under $T_{\mathrm{A}}$ conditions ranging from $12.5^{\circ}$ to $30{ }^{\circ} \mathrm{C}$ and $R_{\mathrm{H}} 60$ to $85 \%$ (McManus et al. 2009). On the other hand, the respiratory frequency ranged from $80 \pm 13$ to $102 \pm 12$ breaths min $^{-1}$ in Holstein cows protected or not from direct solar radiation (Gebremedhin et al. 2010). Similar results were reported by Santos et al. (2017) with Holstein cows managed under direct solar radiation in a tropical environment. Beatty et al. (2006), working with Bos taurus (Angus) and Bos indicus (Brahma) in climatic chambers, found that when these animals were submitted to a temperature of $35{ }^{\circ} \mathrm{C}$ and humidity of $80 \%$ for 5 days, the $R_{\mathrm{R}}$ remained at 126 and 125 breaths $\min ^{-1}$, respectively. Hot climates may induce a rise in body temperature and respiration rate, which increases energy requirements for maintenance by 7 to $25 \%$ (NRC 1981).

From these reports, the respiratory system is frequently used in conditions of heat stress in an attempt to maintain the thermal equilibrium of European breeds. Results of the present investigation showed that the heat loss by the respiratory system seems to be of little significance for the thermal balance of Nellore cattle managed under shade condition. Maia et al. (2005b) and Fonsêca et al. (2016) provide an interesting discussion about the differences between domestic ruminants selected in temperate and tropical environment over the role of the respiratory tract on the thermal equilibrium. Hansen (2004) described that European cattle breeds tend to lose more heat through respiratory evaporation, and this may constitute a marker of animals that are less adapted to high temperature conditions. In this sense, our findings offer good evidence that the energetic costs of the thermoregulation seem to be lower in Nellore animals when compared to other breeds reared in a tropical environment; physiological responses as lower and stable metabolic heat production, respiratory rate, 
and moderate cutaneous evaporation can confirm this statement. More studies are necessary to understand the thermal balance of Nellore cattle when exposed to direct solar radiation and under condition of lower temperatures $\left(<20^{\circ} \mathrm{C}\right)$, rain, and air displacement, which is very common in pasture and confinement system.

\section{Conclusions}

- An indirect calorimetry system was developed to study the thermal balance of Nellore cattle.

- Under shade conditions and air temperature range from 24 to $35{ }^{\circ} \mathrm{C}$, the metabolic heat production, respiratory rate, and ventilation of mature Nellore cattle remain stable, which is indicative of lower energetic cost to the thermoregulation in comparison with some European breeds reared in a tropical environment.

Acknowledgements This study was supported by the Fundação de Amparo à Pesquisa do Estado de São Paulo (FAPESP), process numbers 2011/17388-6 and 2011/16695-2.

Compliance with ethical standards This research was reviewed and approved by the Sao Paulo State University Animal Care and Use Committee before the study started (Process number: 17.519/14).

\section{References}

Beatty DT, Barnes A, Taylor E, Pethick D, McCarthy M, Maloney SK (2006) Physiological responses of Bos taurus and Bos indicus cattle to prolonged, continuous heat and humidity. J Anim Sci 84:972-985

Brouwer E (1965) In Energy metabolism. [K L Blaxter, editor]. London: Academic Press. Weast, R. C. (editor) (1970-1). The handbook of chemistry and physics. 51st ed. Cleveland, Ohio: Weir, J. B. de V.(1949). J. Phyd., Land. 109, p. 41

Camerro LZ, Maia ASC, Chiquitelli Neto M, Costa CCM, Castro PA (2016) Thermal equilibrium responses in Guzerat cattle raised under tropical conditions. J Therm Biol 60:213-221

Collier RJ, Gebremedhin KG (2015) Thermal biology of domestic animals. Annu Rev Anim Biosci 3:10-20

da Silva RG (2000) Um modelo para a determinação do equilíbrio térmico de bovinos em ambientes tropicais. Braz J Anim Sci 29: $1244-1252$.

da Silva RG, LaScala N Jr, Lima Filho AE, Catharin MC (2002) Respiratory heat loss in the sheep: a comprehensive model. Int $\mathrm{J}$ Biometeorol 46:136-140

da Silva RG, Guilhermino MM, Morais DAEF (2010) Thermal radiation absorbed by dairy cows in pasture. Int J Biometeorol 54:5-11

daSilva RG, La Scala Jr N, Tonhati H (2003) Radiative properties of the skin and haircoat of cattle and other animals. Trans ASAE 46:913918

daSilva RG, Maia ASC (2013) Principles of animal biometeorology. Springer, New York Ed. 1

Finch VA (1985) Comparison of non-evaporative heat transfer in different cattle breeds. Aust J Agric Res 36:497-508

Fonsêca VFC, Saraiva EP, Maia ASC, Nascimento CN, Silva JA, Pereira WE, Almeida MEV, Pimenta Filho EC (2016) Models to predict both sensible and latent heat transfer in the respiratory tract of the Morada Nova sheep under semiarid tropical environment. Int $\mathrm{J}$ Biometeorol. doi:10.1007/s00484-016-1255-3

Gaughan JB, Mader TL, Holt SM, Josey MJ, Rowan KJ (1999) Heat tolerance of Boran and Tuli crossbred steers. J Anim Sci 77:23982405

Gebremedhin KG, Cramer CO, Porter WP (1981) Predictions and measurements of heat production and food and water requirements of Holstein calves in different environments. Trans ASAE 3:715-720

Gebremedhin KG, Hillman PE, Lee CN, Collier RJ, Willard ST, Arthington JD, Brown-Brandl TM (2008) Sweating rates of dairy cows and beef heifers in hot conditions. Transaction of the ASABE 51:2167-2178

Gebremedhin KG, Lee CN, Hillman PE, Collier RJ (2010) Physiological responses of dairy cows during extended solar exposure. Trans ASABE 53:239-247

Gonzalez JE, Blaxter KL (1962) The metabolism and thermal regulation of calves in the first month of life. Brit J Nutr 16:199-212

Hansen PJ (2004) Physiological and cellular adaptations of zebu cattle to thermal stress. Anim Reprod Sci 83:349-360

Harvey W R (1960) Least-squares analysis of data with unequal subclass numbers, Beltaville: U.S.D.A, ${ }^{\circ}{ }^{20-8}$

Holmes CW, McLean NA (1975) Effect of air temperature and air movement on the heat produced by young Friesian and Jersey calves, with some measurements of the effects of artificial rain. $\mathrm{N} Z \mathrm{~J}$ Agric Res $18: 277-288$

Incropera FP, DeWitt DP, Bergagman TL, Lavine AS (2013) Fundamentals of heat and mass transfer. J. Wiley, New York

Kibler H H, Brody S (1956) Influence of diurnal temperature cycles on heat production and cardiorespiratory activities in Holstein and Jersey cows. Research bulletin 601, University of Missouri College of Agriculture Agricultural Experiment Station, February

Lighton JRB (2008) Measuring metabolic rates: a manual for scientists. Oxford University Press, New York 201p

Littell RC, Freund RJ (1991) Spector, P. C. SAS® System for Linear Models, third edition. SAS Institute Inc, Cary, NC 329p

Maia A S C, Gebremedhin K G, Nascimento S T, Carvalho M D, Simão B R, Camerro L Z, Chiquitelli Neto M (2014) Development of facial masks for indirect calorimetric studies for livestock. ASABE and CSBE/SCGAB Annual International Meeting Sponsored by ASABE - Montreal, Quebec, Canada

Maia A S C, Silva RG, Loureiro C M B (2005a) Sensible and latent heat loss from the body surface of Holstein cows in a tropical environment. Int J Biometeorol 50:17-22

Maia AS, da Silva RG, Loureiro CMB (2005b) Respiratory heat loss of Holstein cows in a tropical environment. Int J Biometeorol 49:332336

Milan HFM, Maia ASC, Gebremedhin KG (2016) Technical note: device for measuring respiration rate of cattle under field conditions. J Anim Sci, v 94:1-5

McLean JA (1963a) Measurement of cutaneous moisture vaporization from cattle by ventilated capsules. J Physiol 167:417-426

McLean JA (1963b) The partition of insensible losses of body weight in heat from cattle under various climatic conditions. J Physiol 167: 427-447

McLean JA (1972) On the calculation of heat production from open circuit calorimetric measurements. Br J Nutr 27:597-600

McLean JA, Whitmore BA, Young BA, Weingardt R (1984) Body heat storage, metabolism and respiration of cows abruptly exposed and acclimatized to cold and $18{ }^{\circ} \mathrm{C}$ environments. Can J Anim Sci 64: 641-653

McManus C, Castanheira M, Paiva SR, Louvandini H, Fioravanti MCS, Paludo GR, Bianchini E, Corrêa PS (2011) Use of multivariate analyses for determining heat tolerance in Brazilian cattle. Trop Anim Health Prod 43:623-630 
McManus C, Prescott E, Paludo GR, Bianchini E, Louvandini H, Mariante AS (2009) Heat tolerance in naturalized Brazilian cattle breeds. Livest Sci 120:256-264

NRC (1981) Effect of environment on nutrient requirements of domestic animals. National Academy Press, Washington, D.C.

Richardson EC, Herd RM, Oddy VH, Thompson JM, Archer JA, Arthur PF (2001) Body composition and implications for heat production of Angus steer progeny of parents selected for and against residual feed intake. Aust J Exp Agric 41:1065-1072

Santos SGCG, Saraiva EP, Pimenta Filho EC, Gonzaga Neto S, Fonsêca VFC, Pinheiro AC, Almeida EV, Amorin MLC (2017) The use of simple physiological and environmental measures to estimate the latent heat transfer in crossbred Holstein cows. Int J Biometeorol $61: 217-225$
SAS Institute (1995) User's guide: statistics. Version 6.(10 edition).SAS Institute Inc., Cary, NC. 295 pp.

Schleger AV, Turner HG (1965) Sweating rates of cattle in the field and their reaction to diurnal and seasonal changes. Aust J Agric Res 16: 92-106

Schrama JW, Van der Hel W, Arieli A, Verstegen MWA (1992) Alteration of energy metabolism of calves fed below maintenance during 6 to 14 days of age. J Anim Sci 40:2527

Steketee J (1973) Spectral emissivity of skin and pericardium. Phys Med Biol 18:686

Thompson M L (1962) “Melanins". In: Comparative biochemistry. New York: Academics Press, Vol. 3 